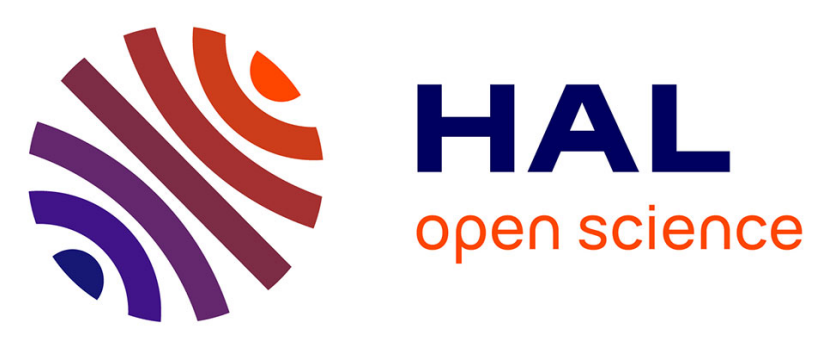

\title{
Evolution of the stratospheric polar vortex in the Southern and Northern Hemispheres over the period 1979-2020
}

\author{
Audrey Lecouffe, Sophie Godin-Beekmann, Andrea Pazmino, Alain \\ Hauchecorne
}

\section{To cite this version:}

Audrey Lecouffe, Sophie Godin-Beekmann, Andrea Pazmino, Alain Hauchecorne. Evolution of the stratospheric polar vortex in the Southern and Northern Hemispheres over the period 1979-2020. EGU General Assembly 2021, Apr 2021, Online Meeting, France. pp.EGU21-9523, 10.5194/egusphereegu21-9523 . insu-03211322

\section{HAL Id: insu-03211322 \\ https://hal-insu.archives-ouvertes.fr/insu-03211322}

Submitted on 28 Apr 2021

HAL is a multi-disciplinary open access archive for the deposit and dissemination of scientific research documents, whether they are published or not. The documents may come from teaching and research institutions in France or abroad, or from public or private research centers.
L'archive ouverte pluridisciplinaire HAL, est destinée au dépôt et à la diffusion de documents scientifiques de niveau recherche, publiés ou non, émanant des établissements d'enseignement et de recherche français ou étrangers, des laboratoires publics ou privés.

\section{(c) (1) $\$$}

Distributed under a Creative Commons Attribution - NonCommerciall 4.0 International 
EGU21-9523, updated on 28 Apr 2021

https://doi.org/10.5194/egusphere-egu21-9523

EGU General Assembly 2021

(c) Author(s) 2021. This work is distributed under

the Creative Commons Attribution 4.0 License.

\title{
Evolution of the stratospheric polar vortex in the Southern and Northern Hemispheres over the period $1979-2020$
}

\author{
Audrey Lecouffe, Sophie Godin-Beekmann, Andrea Pazmiño, and Alain Hauchecorne \\ LATMOS, UVSQ, SORBONNE UNIVERSITE, CNRS, Paris, France (audrey.lecouffe@latmos.ipsl.fr)
}

The stratospheric polar vortex in the Southern Hemisphere plays an important role in the intensity of the stratospheric ozone destruction during austral spring, which started in the late 1970s. The so-called ozone hole has in turn influenced the evolution of weather patterns in the Southern Hemisphere in the last decades (WMO, 2018). The Northern Hemisphere polar vortex is less stable because of larger dynamical activity in winter. It is thus less cold and polar arctic ozone losses are less important. The seasonal and interannual evolution of the polar vortex in both hemispheres has been analyzed using meteorological fields from the European Center for Meteorology Weather Forecasts ERA-Interim reanalyses and the MIMOSA model (Modélisation Isentrope du transport Méso-échelle de l'Ozone Stratosphérique par Advection, Hauchecorne et al., 2002). This model provides high spatial resolution potential vorticity (PV) and equivalent latitude fields at several isentropic levels $(675 \mathrm{~K}, 550 \mathrm{~K}$ and $475 \mathrm{~K})$ that are used to evaluate the temporal evolution of the polar vortex edge. The edge of the vortex is computed on isentropic surfaces from the wind and gradient of PV as a function of equivalent latitude (e.g. Nash et al, 1996; Godin et al., 2001). On an interannual scale, the signature of some typical forcings driving stratospheric natural variability such as the 11-year solar cycle, the quasi-biennial oscillation (QBO), and El Niño Southern Oscillation (ENSO) is evaluated. The study includes analysis of the onset and breakup dates of the polar vortex, which are determined from the wind field along the vortex edge. Several threshold values, such as $15.2 \mathrm{~m} / \mathrm{s}, 20 \mathrm{~m} / \mathrm{s}$ and $25 \mathrm{~m} / \mathrm{s}$ following Akiyoshi et al. (2009) are used. Results on the seasonal and interannual evolution of the intensity and position of the vortex edge, as well as the onset and breakup dates of the Southern and Northern polar vortex edge over the 1979 - 2020 period will be shown.

\section{References:}

- Akiyoshi, H., Zhou, L., Yamashita, Y., Sakamoto, K., Yoshiki, M., Nagashima, T., Takahashi, M., Kurokawa, J., Takigawa, M., and Imamura, T. A CCM simulation of the breakup of the Antarctic polar vortex in the years 1980-2004 under the CCMVal scenarios, Journal ofGeophysical Research: Atmospheres, 114, 2009.

- Godin S., V. Bergeret, S. Bekki, C. David, G. Mégie, Study of the interannual ozone loss and the permeability of the Antarctic Polar Vortex from long-term aerosol and ozone lidar measurements in Dumont d'Urville (66.4ロS, 1400E), J. Geophys. Res., 106, 1311-1330, 2001.

- Hauchecorne, A., S. Godin, M. Marchand, B. Hesse, and C. Souprayen, Quantification of the 
transport of chemical constituents from the polar vortex to midlatitudes in the lower stratosphere using the high-resolution advection model MIMOSA and effective diffusivity, J. Geophys. Res., 107 (D20), 8289, doi:10.1029/2001JD000491, 2002.

- Nash, E. R., Newman, P. A., Rosenfield, J. E., and Schoeberl, M. R. (1996), An objective determination of the polar vortex using Ertel's potential vorticity, Journal of geophysical research, VOL.101(D5), 9471- 9478

- World Meteorological Organization, Global Ozone Research and Monitoring Project - Report No. 58, 2018. 